\title{
THE INFLUENCE OF OIL PRICES ON INDONESIA'S EXCHANGE RATE
}

\author{
Seema Wati Narayann', Telisa Falianty ${ }^{2}$, Lutzardo Tobing ${ }^{3}$ \\ ${ }^{1}$ School of Economics, Finance \& Marketing, Royal Melbourne Institute of Technology University, \\ Melbourne, Australia. Email: seema.narayan@rmit.edu.au \\ ${ }^{2}$ Faculty of Economics and Business, Universitas Indonesia. Email: telisa97fe@gmail.com \\ ${ }^{3}$ Bank Indonesia Institute, Bank Indonesia, Jakarta, Indonesia. Email: lutzardo@bi.go.id
}

\begin{abstract}
This study tests for a long-run relation between oil prices and the rupiah-US dollar exchange rate. We discover, first, that the long-run cointegration relation between oil prices and the real exchange rate $(R E R)$ is sensitive to different exchange rate regimes in Indonesia. Second, we find a long-run cointegrating relation between oil prices and the $R E R$ over the float exchange rate regime. However, in the managed float period, there is no evidence of a long-run relation between oil prices and the RER. In the long run, higher oil prices lead to an appreciation of the rupiah against the US dollar in the float period (post-August 1997 period). We demonstrate that these results are robust to different data frequencies.
\end{abstract}

Keywords: Cointegration; Exchange rate regime; Oil price; Real exchange rate.

JEL Classifications: E31; F31; Q43.

Article history:

Received : : September 15, 2018

Revised : January 4, 2019

Accepted : January 4, 2019

Available online : January 30, 2019

https://doi.org/10.21098/bemp.v21i3.1007 


\section{INTRODUCTION}

We examine the long-run linkage between exchange rate and oil price changes for Indonesia. Indonesia presents an interesting case, being an exporter as well as an importer of crude oil and partly refined petroleum (see Figure 1). Over most of our study period, Indonesia was a net exporter (exports $>$ imports) of crude oil and partly refined petroleum and only became a net importer (exports $<$ imports) since 2013, although it became a net importer of partly refined petroleum products since 1996 (see Section II.B for details). Under conditions of higher oil prices, Indonesia, as an oil-exporting (oil-importing) nation, could experience an appreciation (depreciation) of its exchange rate, since economic theory suggests that wealth is transferred from the importer nation to the exporter nation as oil prices increase (Golub, 1983; Krugman, 1983). As a net exporter of crude oil up until 2012 and a net exporter of partly refined petroleum since 1996, on average, we can expect an appreciating effect of oil price changes over our study period from 1986 to 2017.

Nonetheless, to keep petrol and related products affordable, the Indonesian government has been offering price subsidies on petroleum and related products (Narayan, 2013). The policy of oil price subsidies is active throughout out study period. The price subsidy was introduced in the 1970s, when Indonesia was a net oil exporter. The latest regulations in oil subsidies on gasoline, diesel, and kerosene prices were enforced in 2013 (Ministry of Energy and Mineral Resources, 2013). The price subsidy on gasoline was abandoned in 2014 but the price subsidies on diesel and kerosene prices are still maintained. Under such policy interventions, several analysts argue that the upward pressure on oil prices has increased, which can eventually have a bigger impact on exchange rates with price subsidies than on exchange rates without them (see Narayan, 2013).

At the same time, Indonesia has seen changes in its exchange rate regimes over time. Indonesia adopted a float regime in August 1997, followed by a managed float exchange rate system between November 1978 and July 1997, with a crawling band system adopted between September 1992 and July 1997 (Table 1). We account for the regime changes over the period 1990-2017 from managed float to float regimes in our examination of the link between the exchange rate and oil prices. Although, in the float regime the central bank of Indonesia, Bank Indonesia, continued to implement exchange rate stabilization measures in line with the currency's fundamental value, the managed float regime experienced more interventions than the float regime.

Table 1.

Indonesia's Exchange Rate Regimes: 1945 to Present

This table provides a chronology on the exchange rate regimes adopted in Indonesia since 1945.

\begin{tabular}{lc}
\hline Period & Regime \\
\hline $1945-1959$ & Multiple exchange rate system \\
$1959-1966$ & Fixed exchange rate \\
November 1978-September 1992 & Managed floating \\
September 1992 - July 1997 & Managed floating (crawling band system) \\
August 1997 - onwards & Floating system \\
\hline
\end{tabular}

Source: Simorangkir and Suseno (2004). 
Various studies show difference in the behaviours of macroeconomic factors at different exchange rate regimes (Mundell, 1995; Rolnick and Weber, 1997; Yeyati and Sturzenegger, 2003; Husain, Mody, and Rogoff, 2005). Rolnick and Weber (1997) show that output growth is higher under fiat standards than under commodity standards. In their study of the association between de facto exchange rate regimes and economic growth over the post-Bretton Woods period (1974-2000), Yeyati and Sturzenegger (2003) find that, in developing countries, less flexible exchange rate regimes are associated with slower growth while more flexible regimes are associated with greater output volatility. The authors find no such links for industrial countries (see also Mundell, 1995). Husain, Mody, and Rogoff (2005) evaluate regime performance in terms of inflation, growth, and crisis outcomes between developing, emerging, and advanced economies. They find evidence that, for developing countries, fixed exchange rate regimes lower inflation and more flexible regimes are associated with higher inflation, but with no evident gains in growth. They find similar evidence for emerging countries, but with small differences (and not always significant). On the other hand, more flexible regimes in advanced countries are associated with lower inflation and higher growth.

The question we ask in this paper, is whether the reaction of the exchange rate to oil prices differs between the managed float and float regimes. Evidence documented in this literature, particularly those from the work of Husain et al. (2005) imply that we expect to see differences in the reaction of the exchange rate to oil price changes between the managed float and float regimes. Husain et al. (2005) show that, for developing nations, inflation is lower in fixed exchange rate regimes compared to more flexible regimes. Hence, for Indonesia, we expect that, under the managed float regime, exchange rate management will be more in tune with changes in oil prices than under the float regime. In other words, the effect of oil prices will be lower under managed float regime than the float regime.

Interestingly, current evidence on the reaction of the exchange rate to oil price changes covers managed float and float regimes with no distinction between the regimes. Further evidence suggests no short-term link between the exchange rate and oil prices. Narayan (2013) finds, under a predictive modelling framework, that Indonesia's exchange rate, in nominal terms, is unrelated to oil prices in both the in-sample and out-of-sample forecasting exercises. Moreover, the author shows that the exchange rate is significantly related to the oil prices of other nations, such as Vietnam, Bangladesh, Cambodia, and Hong Kong. Recently, Narayan and Sahminan (2018) and Narayan et al. (2019) have re-examined the exchange rate model in real terms, where the main focus is on the implications of cryptocurrency and fintech, respectively. More importantly, these studies also account for the effects of oil prices but find prices to be insignificantly related to the RER.

The disconnect between the exchange rate and oil prices that we note in the literature is a feature of short-term models. The aim of this paper is to test whether this disconnect between oil prices and the exchange rate is just a shortterm phenomenon or also a long-term phenomenon. One likely explanation for this disconnect is that studies have not accounted for changes in the exchange rate regimes (Narayan and Sahminan, 2018). Therefore, we use an exchange rate model similar to that proposed for Indonesia by Narayan et al. (2018) and 
Narayan and Sahminan (2018). One difference is that we cover a longer sample period, which allows us to examine the exchange rate-oil price nexus under the managed exchange rate regime prior to August 1997 and a floating exchange rate regime (post-August 1997) for Indonesia. We use a battery of cointegration tests to examine any possible long-run relationship between the exchange rate and oil prices.

The present study is, to the best our knowledge, the first to examine the oil price-exchange rate nexus under different exchange rate regimes (i.e. floating and managed floating systems). Almost every other study on the oil price-exchange rate relation focuses on short-term linkages, with none focused on the effects of different exchange rate regimes (Amano and van Norden, 1998; Camarero and Tamarit, 2002; Chen and Chen, 2007; Lizardo and Mollick, 2010; Basher et al., 2012; Narayan, 2013; Narayan and Sahminan, 2018; Narayan et al. 2018).

\section{EXCHANGE RATE REGIMES AND OIL EXPORTS AND IMPORTS IN INDONESIA: 1986-2018}

A. Exchange Rate Regimes

Over our study period, 1986-2018, Indonesia moved to a new exchange rate regime once. On 14 August 1997, the move to a float regime from a managed float regime was undertaken in the wake of the Asian financial crisis, to prevent further depletion of foreign exchange reserves. The Asian financial crisis resulted in significant capital flight and increased speculation activities against the rupiah that weakened the rupiah exchange rate. This condition was exacerbated by social unrest and political instability in the country. The exchange rate crisis accompanied by social turmoil in the country resulted in hyperinflation and deep economic contraction in 1998.

The subsequent economic recovery that came with a more stable social, economic, and political environment saw the rupiah gaining ground by 2003. To date, the country continues to follow a floating exchange rate regime, where Bank Indonesia implements exchange rate stabilization measures in line with the currency's fundamental value. At the same time, Bank Indonesia strives to maintain market mechanisms backed by financial market-deepening efforts.

\section{B. Exports and Imports of Crude Oil and Partly Refined Petroleum}

From 1989 to 2017, crude oil with partly refined petroleum exports declined by $65 \%$, which was less than the drop of $85 \%$ in exports of partly refined petroleum only. On the other hand, the import of partly refined petroleum increased more than the import of crude oil and partly refined petroleum (261\%). This means that, since the early 2000s, Indonesia has become increasing reliant on imported partly refined petroleum products. During this period, crude oil and partly refined petroleum (HS 2709) exports averaged 74,076 tonnes per day while imports averaged 34,900 tonnes per day (Figure 1). Over the same period, excluding crude oil, partly refined petroleum (HS 2710) exports and imports averaged 15,763 and 43,010 tonnes per day, respectively. 
According to the United Nation's Comtrade Database, Indonesia was a net exporter of crude oil and partly refined petroleum up until 2012. From 2013 to 2017, net imports of crude oil plus refined petroleum averaged 8,735 tonnes per day. Prior to this period (1989-2012), net exports of crude oil plus refined petroleum averaged 49,158 tonnes per day.

However, for partly refined petroleum, excluding crude oil, Indonesia became a net importer much earlier, in 1996 (Figure 1) and its net imports (imports minus exports) of refined petroleum averaged 42,037 tonnes per day from 1996 to 2017.

\section{Figure 1. Indonesia's Exports and Imports of Crude and Refined Petroleum (in Million Tons)}

This figure depicts exports and imports of 'Petroleum oils, oils from bituminous minerals, crude' (HS 2709) and exports and imports of 'Oils petroleum, bituminous, distillates, except crude' (HS 2710). We also provide a balancing figure that is derived after subtracting imports from exports. We refer to this balancing figure net exports (net imports) for HS 2709 and HS 2710, if it takes a positive (negative) value.

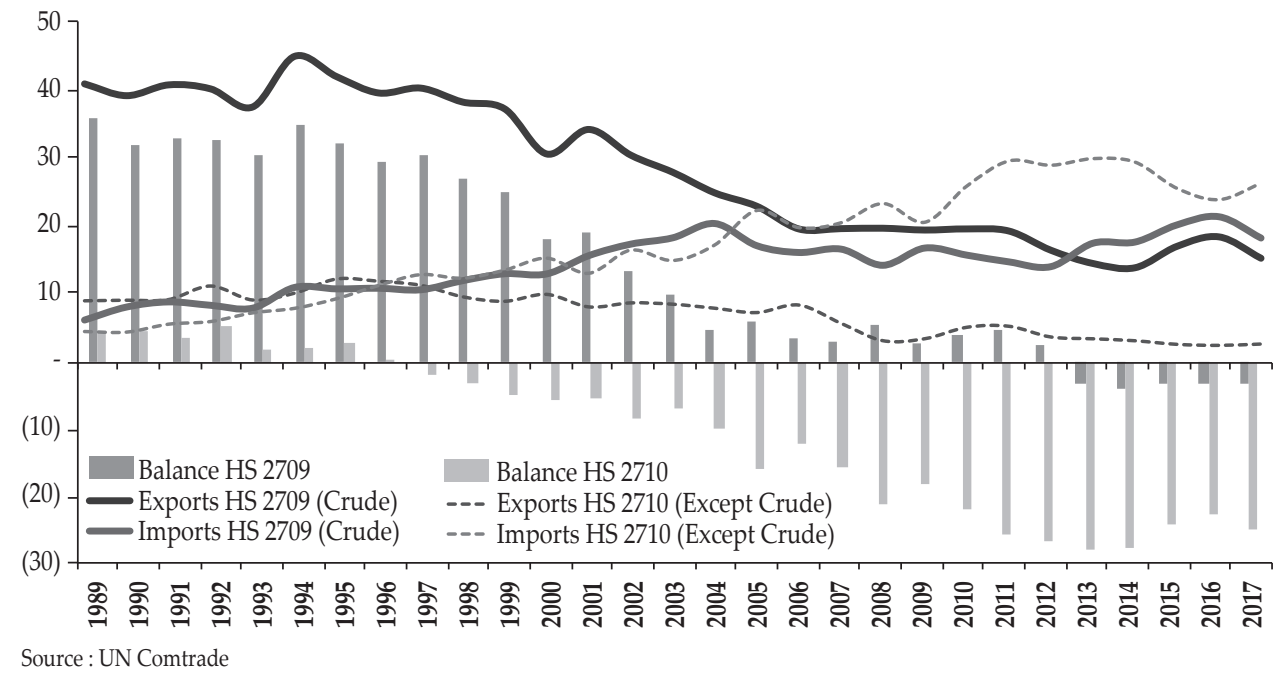

\section{THEORY AND EMPIRICS}

Theoretically, higher oil prices should lead to the transfer of wealth between the exporter and importer of oil (Golub, 1983; Krugman, 1983; Corden, 1984; De Grauwe, 1996). Higher (lower) prices could see appreciation (depreciation) of the exporter currency against the importer currency. However, since the US dollar is the major invoicing and settlement currency in the international market, theoretically, higher (lower) energy prices will increase (reduce) demand for the US dollar (Zhang et al., 2008). In return, increased (reduced) demand for the US dollar should lead to depreciation (appreciation) of the currency of (non-US) importers of energy sources against US currency. Further, if higher prices of crude oil occur simultaneously with higher demand for oil by a non-US importer, the effect could be a much greater depreciation in the non-US importer currency against the US dollar. 
This depreciating effect of higher oil prices for the currencies of other industrialized nations against the US dollar has been noted in various studies (Amano and van Norden, 1998; Camarero and Tamarit, 2002; Chen and Chen, 2007; Lizardo and Mollick, 2010; Basher et al., 2012). Pershin et al. (2016) find that the net oil importing sub-Saharan countries of Botswana, Kenya, and Tanzania behaved differently before and after the oil price shock of July 2008. Ghosh (2011) finds that higher oil prices led to depreciation of the Indian rupee vis-á-vis the US dollar from 2 July 2007 to 28 November 2008. However, Narayan et al. (2008), in a study of Fiji, a net importer of petroleum, show that higher oil prices led to short-term appreciation of the Fiji dollar vis-á-vis the US dollar from 2000 to 2006. Narayan (2013) finds mixed results for selected Asian nations, including Indonesia. The author finds that oil prices are a good in-sample predictor of the nations' exchange rate against the US dollar, although, for some of these countries, a higher oil price was predicted to appreciate the local currency against the US dollar. Narayan (2012) finds that oil prices are not a (short-term) predictor of Indonesia's rupiah against the US dollar. These mixed effects in non-OECD countries could be related to changes in the exchange rate regimes over time or the exchange rate regime been used at the point in time (see discussion in Section 1).

Following uncovered real interest rate parity and the well-known BalassaSamuelson model, we also consider productivity, inflation, and interest rate differentials as theoretically important determinants of the RER. With the exception of Chen and Chen (2007), Narayan et al. (2018), Narayan and Sahminan (2018), the focus has been primarily on the exchange rate and oil prices. We follow the broader exchange rate literature to augment this model to one that includes productivity and real interest rate differentials.

We differ from the literature in that we compare the linkage between the exchange rate and oil prices under different exchange rate regimes, in particular, managed float and float regimes. The motivation is obvious: the relation between exchange rate and oil prices is likely to be dependent on the exchange rate regime.

\section{DATA}

Due to data limitations, a variety of frequencies and data samples were used to arrive at robust findings. The empirical analyses are conducted over three frequencie s: daily, monthly and annual. The real exchange rate $(R E R)$ and West Texas Intermediate (WTI), which proxies for oil prices, are our key variables. Inflation, the interest rate, and productivity differentials are available only at annual and monthly frequencies. Our daily models are in nominal terms, whereas the monthly and annual models are in real terms. The time period varies by data frequency. Daily data cover the period from 9 November 1991 to 26 November 2018, monthly data span the period from January 1986 to April 2018, and annual data cover the period from 1991 to 2017. These data sets cover periods during which Indonesia was a net importer of partly refined petroleum (1997 onwards) and of crude oil and partly refined petroleum (2013 onwards)

On the basis of data availability, daily and monthly data were examined for three subsamples: the full sample, the managed float sample (prior to 14 August 1997), and the float sample (14 August 1997 onwards). An important point is that 
the exchange rate regime change from a managed float to a float coincide with the switch in the status of Indonesia from a net exporter to a net importer of partly refined petroleum. However, when we take crude oil into account then the switch in Indonesia's status from net exporter to net importer occurred during the float regime (2013).

Additionally, since we have more observations with monthly data, we examine the exchange rate-oil nexus over the float sample since the advent of Bitcoin, from August 2011 to April 2018. Here, we want to see passively if the advent of Bitcoin changed the long-run link between the exchange rate and the oil price. ${ }^{4}$ The definitions and sources of all the data series adopted or developed for the paper are presented in Table 2.

Table 2.

Descriptive Statistics

This table reports all the variables used in this study by their definition, and sources of the data used to develop the variables.

\begin{tabular}{|c|c|c|c|}
\hline \multicolumn{4}{|c|}{ Panel A: Daily data } \\
\hline Variables & Definition & Calculations & Source \\
\hline NER & $\begin{array}{l}\text { Exchange rate, expressed } \\
\text { as the number of home } \\
\text { currency units per foreign } \\
\text { currency unit. An increase } \\
\text { in the NER indicates } \\
\text { depreciation of the Rupiah } \\
\text { against the US dollar and } \\
\text { vice versa. }\end{array}$ & $\begin{array}{c}\text { Nominal exchange rate } \\
\left(\frac{\text { USD }}{\text { Rupiah }}\right)\end{array}$ & Bloomberg \\
\hline WTI & West Texas Intermediate & USD per barrel & $\begin{array}{c}\text { Federal Reserve Economic } \\
\text { Data }\end{array}$ \\
\hline \multicolumn{4}{|c|}{ Panel B: Monthly data } \\
\hline Variables & Definition & Calculations & Source \\
\hline$R E R$ & $\begin{array}{l}\text { Real exchange rate, } \\
\text { expressed as the number } \\
\text { of foreign currency units } \\
\text { per home currency unit. } \\
\text { Increase in the RER } \\
\text { indicates appreciation of } \\
\text { the Rupiah against the US } \\
\text { dollar and vice versa. }\end{array}$ & $R E R_{t}=\frac{\text { Rupiah }}{U S D} * \frac{C P I_{\text {Indo }}}{C P I_{U S}}$ & $\begin{array}{c}\text { Nominal exchange rate } \\
\text { is sourced from Global } \\
\text { Financial Database; ticker: } \\
\text { USDIDR; RER is calculated } \\
\text { by the author. }\end{array}$ \\
\hline RIR & $\begin{array}{l}\text { Difference between United } \\
\text { States and Indonesian } \\
\text { 1-month Interbank Rate }\end{array}$ & $\begin{array}{c}R_{I R_{i, t}}=\text { Nominal interbank } \\
\text { rate }_{i, t}-\text { inflation rate } \\
\text { is the US or Indonesia; } i \\
R I R 1_{t}=R I R_{\text {Indo, },}-R I R_{U S, t}\end{array}$ & $\begin{array}{c}\text { Nominal interest rate: } \\
\text { Global Financial Database; } \\
\text { CPI - International } \\
\text { Financial Statistics; Inflation } \\
\text { - author's calculations }\end{array}$ \\
\hline WTI & West Texas Intermediate & USD per barrel & Global Financial Database \\
\hline
\end{tabular}

4 To see exchange rate models with Bitcoin and oil prices, see Narayan et al. (2019). 
Table 2.

Descriptive Statistics (Continued)

\begin{tabular}{|c|c|c|c|}
\hline \multicolumn{4}{|c|}{ Panel C: Annual data } \\
\hline Variables & Definition & Calculations & Source \\
\hline WTI & $\begin{array}{l}\text { Crude Oil Prices: West } \\
\text { Texas Intermediate }\end{array}$ & USD per barrel & CEIC \\
\hline RER & $\begin{array}{c}\text { Real exchange rate, } \\
\text { expressed as the US dollar } \\
\text { in terms of Rupiah. Increase } \\
\text { in the RER indicates } \\
\text { depreciation of the Rupiah } \\
\text { against the US dollar and } \\
\text { vice versa. }\end{array}$ & $R E R_{t}=\frac{U S D}{\text { Rupiah }} * \frac{C P I_{U S}}{C P I_{I N D O}}$ & $\begin{array}{l}\text { Nominal exchange rate is } \\
\text { sourced from CEIC; RER } \\
\text { is calculated by the author. }\end{array}$ \\
\hline$D Y$ & $\begin{array}{l}\text { Difference of the } \\
\text { productivity }(Y) \text { between } \\
\text { the US and Indonesia }\end{array}$ & $\begin{array}{c}D Y=Y_{\text {Indonesia }}-Y_{u S^{\prime}} \text { where } \\
Y_{\text {Indonesia }}=\log \left(R G D P_{\text {Indonesia }}\right)- \\
\log (\text { Employment } \\
\text { and } \\
Y_{\text {Indonesia }}=\log \left(R G D P_{u S}\right)- \\
\log \left(\text { Employment }{ }_{U S}\right)\end{array}$ & $\begin{array}{l}\text { Indonesia and US RGDP } \\
\text { (USDb) and Employment } \\
\text { (no. of person) data - CEIC; } \\
\text { DY - author's calculations }\end{array}$ \\
\hline
\end{tabular}

Descriptive statistics are presented in Table 3 from the daily and monthly series, we note that, on average, the rupiah is weaker against the US dollar in the float regime compared to the managed float period. The managed float regime is accompanied by a crawling band, which explains why the volatility, measured by the coefficient of variation, during this period is lower than that in the float regime.

Table 3.

\section{Descriptive Statistics}

This table presents descriptive statistics for variables in daily form: NER and WTI; Monthly: RER, WTI, and RIR; and Annual: RER, WTI, RIR, and DY. The variables are defined in Table 2. Note the definition of the Rupiah-US exchange rate: ${ }^{\mathrm{a} U S} / \mathrm{Rupiah}{ }^{\mathrm{b}} \mathrm{Rupiah} /$ US. The descriptive statistics are for the full sample, floating and managed-floating period. The columns entitled $R E R^{\mathrm{b}}$ and $R E R$ have their mean, maximum, and minimum, and std. dev. multiplied by 1000 .

\begin{tabular}{|c|c|c|c|c|c|c|c|c|c|}
\hline \multirow{3}{*}{ Full sample } & \multicolumn{2}{|c|}{ Daily } & \multicolumn{3}{|c|}{ Monthly } & \multicolumn{4}{|c|}{ Annual } \\
\hline & \multicolumn{2}{|c|}{$\begin{array}{l}9 \text { Nov 1991- } \\
26 \text { Nov } 2018\end{array}$} & \multicolumn{3}{|c|}{ Jan 1986-April 2018} & \multicolumn{4}{|c|}{ 1991-2017 } \\
\hline & $N E R^{a}$ & WTI & $R E R^{b}$ & WTI & RIR & $R E R^{a}$ & WTI & $R I R$ & DY \\
\hline Mean & 8380 & 48.66 & 0.046 & 43.34 & 2.22 & 11029 & 46.83 & 1.75 & -1.65 \\
\hline $\mathrm{CV}$ & 0.45 & 0.62 & 0.23 & 0.68 & 2.72 & 0.27 & 0.63 & 2.35 & -0.18 \\
\hline Maximum & 16650 & 145.31 & 0.075 & 133.88 & 42.56 & 21066 & 99.67 & 11.88 & -1.17 \\
\hline Minimum & 1980 & 0.00 & 0.014 & 11.35 & -43.50 & 7999 & 14.42 & -7.19 & -1.91 \\
\hline Std. Dev. & 3741 & 30.08 & 0.01 & 29.61 & 6.06 & 3009 & 29.42 & 4.11 & 0.30 \\
\hline Obs. & 6911 & 6911 & 383 & 388 & 337 & 28 & 28 & 20 & 28 \\
\hline
\end{tabular}


Table 3.

Descriptive Statistics (Continued)

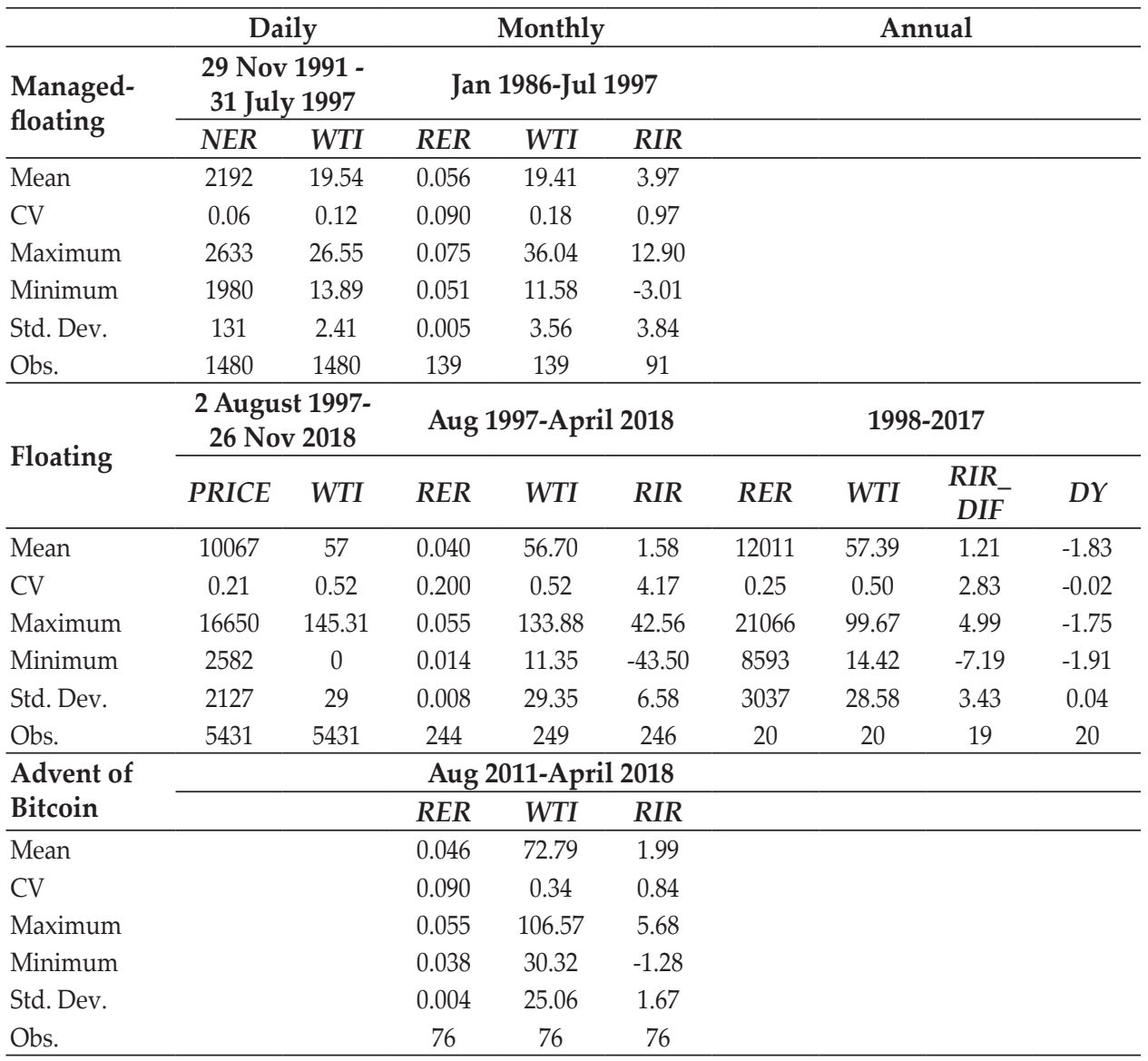

Looking at the monthly RER series over the float regime and the Bitcoin period, we note that the Bitcoin period coincides with an average appreciation of the rupiah against the US dollar. Further, the RER is less volatile in the period Bitcoin was introduced than in the period prior to its introduction.

Oil prices are, on average, higher during the float period than in the managed float regime. In recent years (which marks the advent of Bitcoin), oil prices have reached new heights. Oil prices were most volatile during the float period compared to the managed float and recent years.

The other two determinants of the $R E R$ are the real interest rate differential $(R I R)$ and the productivity differential (DY) between Indonesia and the United States. The RIR is the most volatile series of all the data. The series most volatile in the float period but, on average, highest in the managed float period. The $D Y$ values are best developed with annual data (see Table 2 for definition).

Next, we examine the time series properties of our data. All variables, except $R I R$, are expressed in logarithmic form. The unit root test is performed before 
conducting the cointegration tests. We use three cointegration tests, of which the Engle-Granger (1987; hereafter EG) test and the Johansen (1998, 1991, 1995) test can only be conducted for I(1) variables and the third test, the autoregressive distributed lag (ARDL; see Pesaran and Shin, 1995) approach to cointegration, uses both $\mathrm{I}(0)$ and $\mathrm{I}(1)$ variables but not $\mathrm{I}(2)$ variables. We use the conventional augmented Dickey-Fuller (ADF) test to evaluate the null of a unit root against the alternative of no unit root. ${ }^{5}$ This test is conducted on all variables across the full sample and various subsamples for each of the three frequencies.

The results are reported in Table 4 . Note that, as highlighted in Section II, the timeline for each frequency is different, which explains why we obtain different results across frequencies. We find that the daily oil price (WTI) and the nominal exchange rate (NER) are I(1) or stationary in the first differenced form in the full sample and all the other subsamples, except for NER in the (free) float period. This means that we can apply the Engle-Granger and Johansen methods to all the samples except during the float period when using daily data. The ARDL method is applicable to the full sample and subsamples of the daily data.

The monthly WTI and RER are stationary in level form the full sample and managed float periods but nonstationary in level form in the float regime, suggesting the applicability of all three methods of cointegration in the latter regime but only the use of the ARDL method in the former regime. All annual series are stationary after being differenced only once, which indicates that all three cointegrating methods apply when annual data are used.

\section{Table 4.}

\section{Unit Root Test Results}

This table presents the ADF test results, the test statistic and the corresponding probability value (in parenthesis) for all the variables used by three different data frequencies and sample periods. Lag length(s) were selected automatically using Akaike Information Criteria. The null of unit root is tested against the alternative of no unit root. Finally, ${ }^{*}, * *$, and ${ }^{* * *}$ denote statistical significance at the $10 \%, 5 \%$ and $1 \%$ levels, respectively.

\begin{tabular}{|c|c|c|c|c|c|c|}
\hline \multirow{3}{*}{ Frequency: } & \multirow{2}{*}{\multicolumn{2}{|c|}{$\begin{array}{c}\text { Daily } \\
\text { Nominal }\end{array}$}} & \multirow{2}{*}{\multicolumn{2}{|c|}{$\begin{array}{c}\text { Monthly } \\
\text { Real }\end{array}$}} & \multirow{2}{*}{\multicolumn{2}{|c|}{$\begin{array}{c}\text { Annual } \\
\text { Real }\end{array}$}} \\
\hline & & & & & & \\
\hline & $\mathrm{I}(0)$ & $\mathrm{I}(1)$ & $\mathrm{I}(0)$ & $\mathrm{I}(1)$ & $\mathrm{I}(0)$ & $\mathrm{I}(\mathbf{1})$ \\
\hline Full Sample & \multicolumn{2}{|c|}{$\begin{array}{l}9 \text { Nov 1991- } \\
26 \text { Nov } 2018\end{array}$} & Jan 19 & il 2018 & \multicolumn{2}{|c|}{ 1991-2017 } \\
\hline WTI & $\begin{array}{l}-1.551 \\
{[0.508]}\end{array}$ & $\begin{array}{c}-84.665^{* * *} \\
{[0.000]}\end{array}$ & $\begin{array}{l}-3.456 \\
{[0.011}\end{array}$ & & $\begin{array}{l}-1.061 \\
{[0.716]}\end{array}$ & $\begin{array}{c}-4.710^{* * *} \\
{[0.001]}\end{array}$ \\
\hline$E R$ & $\begin{array}{l}-1.822 \\
{[0.370]}\end{array}$ & $\begin{array}{c}-10.867^{* * *} \\
{[0.000]}\end{array}$ & $\begin{array}{r}-4.220^{*} \\
{[0.001}\end{array}$ & & $\begin{array}{l}-2.266 \\
{[0.190]}\end{array}$ & $\begin{array}{c}-5.903^{* * * *} \\
{[0.000]}\end{array}$ \\
\hline$D Y$ & & & & & $\begin{array}{l}-1.596 \\
{[0.471]}\end{array}$ & $\begin{array}{c}-5.071^{* * *} \\
{[0.000]}\end{array}$ \\
\hline RIR & & & $\begin{array}{r}-5.189^{*} \\
{[0.000} \\
\end{array}$ & & & \\
\hline
\end{tabular}

5 Narayan and Popp (2010) structural break test was also conducted on full sample data on exchange rate. Results from all frequencies, except daily frequency, are consistent with the reported results. For daily data, Narayan and Popp test suggests stationarity at level form with breaks in 2005:07 and 2008:07. We estimated the daily full sample ARDL model with levels of the NER and the structural breaks and found the findings to be no different from the ones explained in the paper. These results are available on request. 
Table 4.

Unit Root Test Results (Continued)

\begin{tabular}{|c|c|c|c|c|c|c|}
\hline \multirow{3}{*}{ Frequency: } & \multirow{2}{*}{\multicolumn{2}{|c|}{$\begin{array}{c}\text { Daily } \\
\text { Nominal }\end{array}$}} & \multirow{2}{*}{\multicolumn{2}{|c|}{$\begin{array}{c}\text { Monthly } \\
\text { Real }\end{array}$}} & \multirow{2}{*}{\multicolumn{2}{|c|}{$\begin{array}{c}\text { Annual } \\
\text { Real }\end{array}$}} \\
\hline & & & & & & \\
\hline & $\mathrm{I}(0)$ & I(1) & $\mathrm{I}(0)$ & $\mathrm{I}(1)$ & $\mathrm{I}(0)$ & $\mathrm{I}(1)$ \\
\hline $\begin{array}{l}\text { Managed- } \\
\text { floating regime }\end{array}$ & \multicolumn{2}{|c|}{$\begin{array}{l}29 \text { Nov } 1991 \text { - } \\
31 \text { July } 1997\end{array}$} & \multicolumn{2}{|c|}{ Jan 1986-Jul 1997} & & \\
\hline WTI & $\begin{array}{l}-2.813 \\
{[0.057]}\end{array}$ & $\begin{array}{c}-38.024^{* * *} \\
{[0.000]}\end{array}$ & \multicolumn{2}{|c|}{$\begin{array}{l}-4.047^{* * *} \\
{[0.002]}\end{array}$} & & \\
\hline$E R$ & $\begin{array}{c}1.518 \\
{[0.999]}\end{array}$ & $\begin{array}{c}-16.642^{* * *} \\
{[0.000]}\end{array}$ & \multicolumn{2}{|c|}{$\begin{array}{c}-4.206^{* * *} \\
{[0.001]}\end{array}$} & & \\
\hline RIR & & & $\begin{array}{l}-1.171 \\
{[0.684]}\end{array}$ & $\begin{array}{c}-8.812^{* * *} \\
{[0.000]}\end{array}$ & & \\
\hline Floating regime & \multicolumn{2}{|c|}{$\begin{array}{c}2 \text { August } 1997- \\
26 \text { Nov } 2018\end{array}$} & \multicolumn{2}{|c|}{ Aug 1997-April 2018} & \multicolumn{2}{|c|}{ 1998-2017 } \\
\hline WTI & $\begin{array}{l}-1.790 \\
{[0.386]}\end{array}$ & $\begin{array}{c}-75.333^{* * *} \\
{[0.000]}\end{array}$ & $\begin{array}{l}-2.484 \\
{[0.121]}\end{array}$ & $\begin{array}{c}-10.530^{* * *} \\
{[0.000]}\end{array}$ & $\begin{array}{l}-1.388 \\
{[0.568]}\end{array}$ & $\begin{array}{l}-4.296^{* * *} \\
{[0.003]}\end{array}$ \\
\hline$E R$ & $\begin{array}{l}-5.418^{* * *} \\
{[0.000]}\end{array}$ & & $\begin{array}{l}-1.866 \\
{[0.348]}\end{array}$ & $\begin{array}{c}-11.890^{* * *} \\
{[0.000]}\end{array}$ & $\begin{array}{c}-2.649 \\
{[0.100]}\end{array}$ & $\begin{array}{c}-5.279^{* * *} \\
{[0.000]}\end{array}$ \\
\hline RIR & & & $\begin{array}{l}-2.001 \\
{[0.286]} \\
\end{array}$ & $\begin{array}{c}-15.371^{* * *} \\
{[0.000]} \\
\end{array}$ & & \\
\hline $\begin{array}{l}\text { Advent of } \\
\text { Bitcoin }\end{array}$ & & & \multicolumn{2}{|c|}{ Aug 2011-April 2018} & & \\
\hline WTI & & & $\begin{array}{l}-1.458 \\
{[0.550]}\end{array}$ & $\begin{array}{l}-6.330 \\
{[0.000]}\end{array}$ & & \\
\hline$E R$ & & & $\begin{array}{l}-2.117 \\
{[0.239]}\end{array}$ & $\begin{array}{l}-8.933 \\
{[0.000]}\end{array}$ & & \\
\hline RIR & & & $\begin{array}{l}-2.491 \\
{[0.122]}\end{array}$ & $\begin{array}{l}-7.303 \\
{[0.000]}\end{array}$ & & \\
\hline
\end{tabular}

\section{RESULTS}

A. Cointegration Between the Rupiah-US Dollar Exchange Rate and the Oil Price (WTI) As noted above, three cointegration tests, namely, the Engle-Granger, Johansen, and the ARDL tests, were conducted across all three data frequencies. The cointegration test results are reported in Tables 5 to 8 . Table 5 summarizes the daily and annual cointegration test results and Table 6 presents the monthly results. All three methods are captured here. Tables 7 and 8 provide details on the ARDL models adopted, with Table 7 covering the daily and annual frequencies and Table 8 covering the estimated monthly ARDL models.

Two out of three cointegration tests' results signal the absence of any cointegrating relationship between daily WTI and NER values in the full sample or under the managed floating regime. For both daily frequency subsamples, the results from the ARDL model suggest the presence of a stable long-run relationship, but further investigation suggests that these models fail diagnostic tests (Table 7). Hence, we are unable to find a robust cointegration relationship between NER and WTI. Looking at the monthly data, cointegration of the WTI and $R E R$ series is unanimously supported by all three cointegration tests in the float regime. However, we could not establish a stable long run link between $R E R$ and 
WTI in the more recent period (August 2011 onwards) which marks the advent of the Bitcoin. The ARDL model proves to be more supportive of a stable long-run relation with annual data for the full sample and the sample covering the float regime. Next, we estimate the long-run elasticities for the monthly and annual models.

\section{Table 5.}

\section{Daily and Annual Cointegration Between WTI and Exchange Rate: Full Sample and/or Managed-Floating or Floating Regimes}

This table presents the daily and annual data model-based results from tests of cointegration between WTI and RER from three different approaches to cointegration: Engle-Granger, Johansen, and the Autoregressive Distributed Lag (ARDL). The ARDL models and their diagnostics are presented in Table 7. Due to data limitations, the daily models comprise of nominal (N) variables while the annual models include variables in real (R) terms. For the diagnostics on the ARDL model, see Table 6 . Finally, ${ }^{*}, * *$, and ${ }^{* * *}$ denote statistical significance at the $10 \%, 5 \%$ and $1 \%$ levels, respectively. \#MacKinnon (1996) $p$-values. Automatic lags specification based on Schwarz Information Criterion. \#\#MacKinnon-Haug-Michelis (1999) $p$-values.

\begin{tabular}{|c|c|c|c|c|c|c|c|c|c|c|c|}
\hline \multirow{3}{*}{$\begin{array}{l}\text { Panel 1: Daily } \\
\text { Engle-Granger }\end{array}$} & \multicolumn{6}{|c|}{ Full Sample } & \multicolumn{5}{|c|}{ Managed-float regime } \\
\hline & \multicolumn{6}{|c|}{ Model 1: WTI, NER } & \multicolumn{5}{|c|}{ Model 1: WTI, NER } \\
\hline & Dependent & tall-stat. & Prob.\# & $z$-Stat. & Prob.\# & $\begin{array}{l}\max \\
\operatorname{lag} \sim\end{array}$ & tau-stat. & Prob.\# & $z$-Stat. & Prob.\# & $\begin{array}{l}\max \\
\operatorname{lag} \sim\end{array}$ \\
\hline & NER & -1.793 & 0.633 & -5.698 & 0.677 & 34 & 0.193 & 0.992 & 0.384 & 0.992 & 23 \\
\hline \multirow[t]{5}{*}{ Johansen } & \multicolumn{11}{|c|}{ Unrestricted Cointegration Rank Test: Trace and Maximum Eigenvalue } \\
\hline & \multicolumn{6}{|c|}{ Max-Eigen } & Trace & \multicolumn{3}{|c|}{ Max-Eigen } & \\
\hline & No. of CE(s) & Stat. & Prob.\#\# & Stat. & Prob.\#\# & & Stat. & Prob.\#\# & Stat. & Prob.\#\# & \\
\hline & None & 6.562 & 0.629 & 4.189 & 0.839 & & 11.198 & 0.200 & 9.685 & 0.233 & \\
\hline & At most 1 & 2.374 & 0.123 & 2.374 & 0.123 & & 1.513 & 0.219 & 1.513 & 0.219 & \\
\hline \multirow[t]{2}{*}{ ARDL } & F-Stat. & & \multicolumn{4}{|c|}{ Prob. F $(10,6846)$} & F-Stat. & \multicolumn{4}{|c|}{$\begin{array}{c}\text { Prob. F } \\
(17,1453)\end{array}$} \\
\hline & $86.600^{* * *}$ & & & 0.4 & 00 & & $4.474^{* * *}$ & & 0.0 & 000 & \\
\hline \multirow{2}{*}{ Panel 2: Annual } & \multicolumn{6}{|c|}{ Full Sample: 19912017} & \multicolumn{5}{|c|}{ Float regime: 19982017} \\
\hline & \multicolumn{6}{|c|}{ Model 1: WTI, RER } & \multicolumn{5}{|c|}{ Model 1: WTI, RER } \\
\hline \multirow[t]{2}{*}{ Engle-Granger } & Dependent & $\begin{array}{c}\text { tau- } \\
\text { statistic }\end{array}$ & Prob.\# & $z$-Stat. & Prob.\# & $\begin{array}{l}\max \\
\operatorname{lag} \sim\end{array}$ & $\begin{array}{c}\text { tau- } \\
\text { statistic }\end{array}$ & Prob.\# & $z$-Stat. & Prob.\# & $\begin{array}{l}\max \\
\log \sim\end{array}$ \\
\hline & RER & -2.298 & 0.393 & -8.581 & 0.391 & 5 & $-3.884^{* *}$ & 0.036 & $-33.92^{* * *}$ & 0.000 & 3 \\
\hline \multirow[t]{4}{*}{ Johansen } & & \multicolumn{2}{|c|}{ Trace } & \multicolumn{2}{|c|}{ Max-Eigen } & & \multicolumn{2}{|c|}{ Trace } & \multicolumn{2}{|c|}{ Max-Eigen } & \\
\hline & No. of $\mathrm{CE}(\mathrm{s})$ & Statistic & Prob.\#\# & Statistic & Prob.\#\# & & Statistic & Prob.\#\# & Statistic & Prob.\#\# & \\
\hline & None & 9.940 & 0.285 & 6.881 & 0.503 & & $9.940^{* * * *}$ & 0.000 & $39.063^{* * *}$ & 0.000 & \\
\hline & At most 1 & $3.059^{*}$ & 0.080 & $3.059^{*}$ & 0.080 & & $3.059^{* *}$ & 0.030 & $4.700^{* *}$ & 0.030 & \\
\hline \multirow[t]{2}{*}{ ARDL } & F-statistic & \multicolumn{4}{|c|}{$\operatorname{Prob}(F-$-statistic$)$} & \multicolumn{3}{|c|}{ F-statistic } & \multicolumn{2}{|c|}{$\operatorname{Prob}(F-$-statistic) } & \\
\hline & $4.176^{* *}$ & & 0.0 & 28 & & & $3.275^{*}$ & & 0.0 & 663 & \\
\hline
\end{tabular}


Table 6.

Monthly and Annual Cointegration Results: With More Variables

This table presents the monthly test results the cointegrating link between WTI and RER (with or without additional theoretically motivated variables) from three different approaches to cointegration: Engle-Granger, Johansen, and the Autoregressive Distributed Lag (ARDL). The ARDL models and their diagnostics are presented in Table 8. CE stands for cointegrating equations. Finally, ${ }^{*}, * *$, and ${ }^{* * *}$ denote statistical significance at $10 \%, 5 \%$ and $1 \%$ levels, respectively.

\begin{tabular}{|c|c|c|c|c|c|c|c|c|c|}
\hline \multicolumn{10}{|c|}{ Monthly data } \\
\hline & Model & \multicolumn{4}{|c|}{ Model 1: WTI, RER } & \multicolumn{4}{|c|}{ Model 2: WTI, RER, RIR } \\
\hline Methods & Sample & \multicolumn{8}{|c|}{ Sample: 2011M08 2017M11 } \\
\hline \multirow[t]{2}{*}{$\begin{array}{l}\text { Engle- } \\
\text { Granger }\end{array}$} & Dep. Var. & tau-stat. & Prob.\# & z-Stat. & Prob.\# & $\begin{array}{l}\text { tau- } \\
\text { stat. }\end{array}$ & Prob.\# & z-Stat. & Prob.\# \\
\hline & RER & -9.017 & 0.000 & -78.53 & 0.000 & -2.581 & 0.451 & -9.85 & 0.592 \\
\hline \multirow[t]{5}{*}{ Johansen } & & \multicolumn{2}{|c|}{ Trace } & \multicolumn{2}{|c|}{ Max-Eigen } & \multicolumn{2}{|c|}{ Trace } & \multicolumn{2}{|c|}{ Max-Eigen } \\
\hline & $\begin{array}{l}\text { No. of } \\
\text { CE(s) }\end{array}$ & Stat. & Prob.\#\# & Stat. & Prob.\#\# & Stat. & Prob.\#\# & Stat. & Prob.\#\# \\
\hline & None & 54.523 & 0.000 & 27.96 & 0.000 & 34.175 & 0.015 & 19.63 & 0.079 \\
\hline & At most 1 & 26.559 & 0.000 & 26.55 & 0.000 & 14.491 & 0.07 & 10.75 & 0.177 \\
\hline & At most 2 & & & & & 3.916 & 0.048 & 3.916 & 0.048 \\
\hline \multirow[t]{4}{*}{ ARDL } & F-stat. & 0.111 & & & & 0.994 & & & \\
\hline & $\begin{array}{c}\text { Prob. } \\
\text { (F-stat. })\end{array}$ & 0.895 & & & & 0.422 & & & \\
\hline & Model & \multicolumn{4}{|c|}{ Model 1: WTI, RER } & \multicolumn{4}{|c|}{ Model 2: WTI, RER, RIR } \\
\hline & Sample & \multicolumn{4}{|c|}{ Sample:1997M08 2018M0 } & \multicolumn{4}{|c|}{ Sample:1997M08 2018M0 } \\
\hline \multirow[t]{2}{*}{ Engle-Granger } & Dep. Var. & tau-stat. & Prob.\# & $z$-Stat. & Prob.\# & $\begin{array}{l}\text { tau- } \\
\text { stat. }\end{array}$ & Prob.\# & $z$-Stat. & Prob.\# \\
\hline & RER & -5.164 & 0.000 & -41.67 & 0.000 & -5.371 & 0.000 & -42.81 & 0.001 \\
\hline \multirow[t]{5}{*}{ Johansen } & & \multicolumn{2}{|c|}{ Trace } & \multicolumn{2}{|c|}{ Max-Eigen } & \multicolumn{2}{|c|}{ Trace } & \multicolumn{2}{|c|}{ Max-Eigen } \\
\hline & $\begin{array}{l}\text { No. of } \\
\text { CE(s) }\end{array}$ & Stat. & Prob.\#\# & Stat. & Prob.\#\# & Stat. & Prob.\#\# & Stat. & Prob.\#\# \\
\hline & None & 30.679 & 0.000 & 27.05 & 0.000 & 91.086 & 0.000 & 55.88 & 0.000 \\
\hline & At most 1 & 3.626 & 0.057 & 3.626 & 0.057 & 35.206 & 0.000 & 29.21 & 0.000 \\
\hline & At most 2 & & & & & 5.996 & 0.014 & 5.996 & 0.014 \\
\hline \multirow[t]{2}{*}{ ARDL } & F-stat. & \multicolumn{4}{|c|}{4.017} & \multicolumn{4}{|c|}{213.574} \\
\hline & $\begin{array}{l}\text { Prob. } \\
\text { (F-stat.) }\end{array}$ & \multicolumn{4}{|c|}{0.000} & \multicolumn{4}{|c|}{0.000} \\
\hline \multicolumn{10}{|c|}{ Annual (1991-2017); Model 2: WTI, RER, DY } \\
\hline \multirow[t]{2}{*}{ Engle-Granger } & Dep. Var. & tau-stat. & & Prob.\# & & $z$-stat. & & Prob.\# & \\
\hline & RER & -5.148 & & 0.006 & & -57.98 & & 0 & \\
\hline Johansen & & & Trace & & & & Max-Eiger & & \\
\hline & $\begin{array}{l}\text { No. of } \\
\text { CE(s) }\end{array}$ & Stat. & & Prob. & & Stat. & & Prob. & \\
\hline & None & 35.6 & & 0.009 & & 22.6 & & 0.03 & \\
\hline & At most 1 & 13 & & 0.114 & & 7.656 & & 0.414 & \\
\hline & At most 2 & 5.343 & & 0.02 & & 5.346 & & 0.02 & \\
\hline ARDL & F-stat. & & & & 171.07 & & & & \\
\hline & $\begin{array}{l}\text { Prob. } \\
\text { (F-stat.) }\end{array}$ & & & & 0 & & & & \\
\hline
\end{tabular}




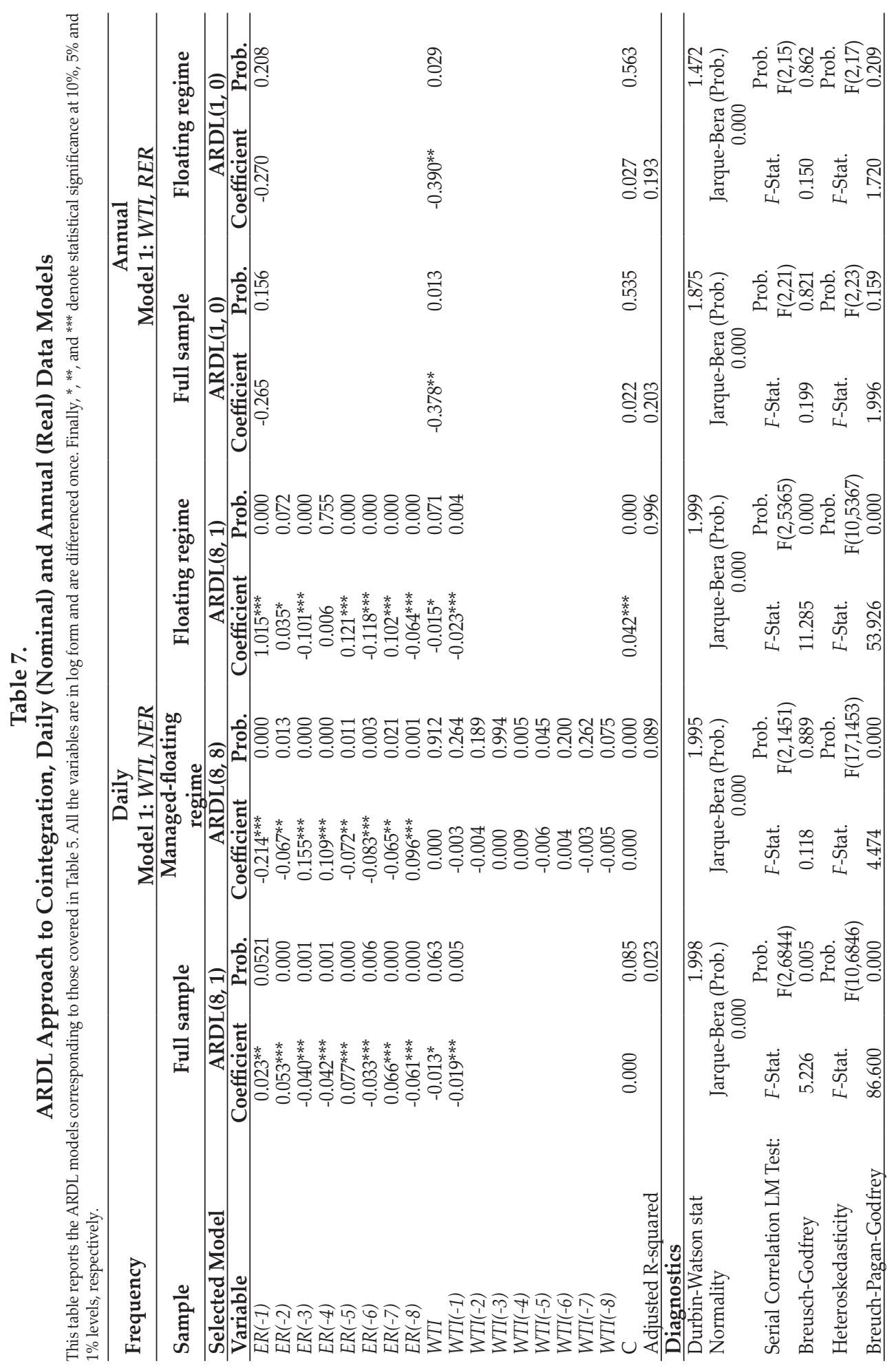




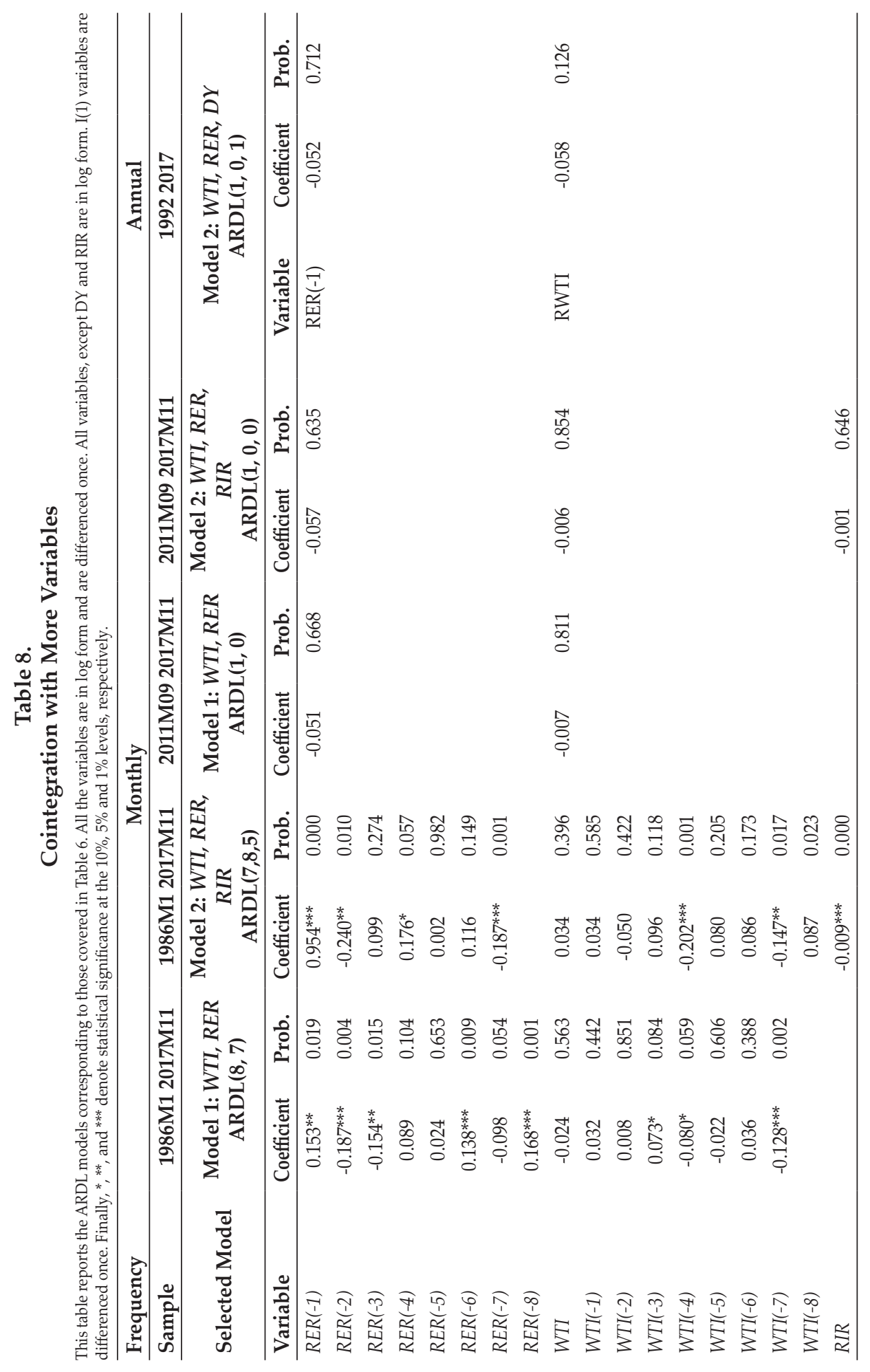




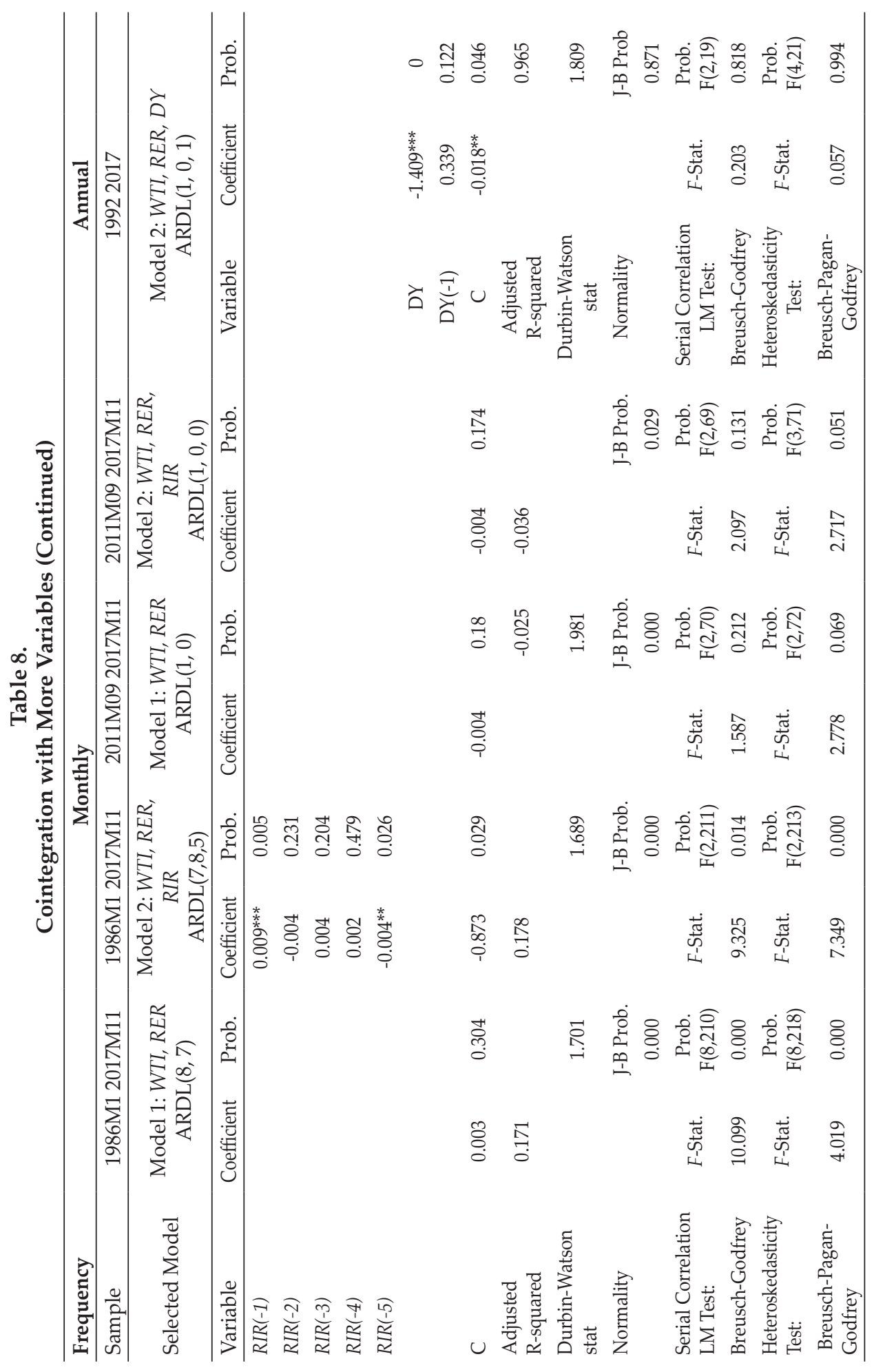




\section{B. Long-run Relationship Between the RER and Oil Prices (WTI)}

In the previous section, we established a long-run cointegrating relationship between monthly and annual RER and WTI values in the float regime. The relationships we focus on (the long-run impact of oil prices on the exchange rate) are dictated by the fact that oil prices and the exchange rate are cointegrated, that is, they share a stable long-run relationship. The long-run models are estimated following the often prescribed dynamic ordinary least squares (DOLS) and fully modified ordinary least squares (FMOLS) methods.

We could not test cointegration for monthly the RER and WTI values in the full sample and managed float regime, since these variables are stationary in level form. For these two samples, we estimate the short-term or first-differenced regression models using robust least squares.

The empirical results are reported in Table 9. Looking at the annual models, we derive the long-run effects of WTI on RER for two samples: the full sample (19912007) and the floating regime sample (1998-2016). For both these samples, we find that WTI has a negative effect on the RER, although the effect of WTI is stronger in the float regime period than in the full sample. Since the annual $R E R$ is measured as foreign currency in terms of the Indonesian rupiah, the negative effect of WTI suggests that higher WTI values reduce the RER or lead to an appreciation of the rupiah against the US dollar. We note this result holds even with the inclusion of additional variables such as $D Y$.

For the monthly RER and WTI, the short-run relationship is negative in the full sample and the managed float sample. The monthly RER data is measured as rupiah in US dollar terms, which means that higher WTI decreases the RER, leading to a depreciation of the rupiah against the US dollar. This is a short-term result that holds when we add a determinant (RIR) of RER. However, in the float regime, where we are able to estimate long-run relationships, we find that the link between monthly RER and WTI values is positive, which implies that higher WTI values increase the $R E R$, leading to an appreciation of the rupiah against the US dollar. This positive result holds with other control factors, such as the RIR (see Table 9). Taken together, the monthly results suggest that, in the managed float period, when Indonesia was always a net exporter of crude oil and partly refined petroleum, the RER and WTI price behave in a theoretically inconsistent manner, at least in the short run. However, during the float regime, when Indonesia was still a net exporter of crude oil for the most part, the appreciating effect of oil prices in the long run aligns well with theory. 


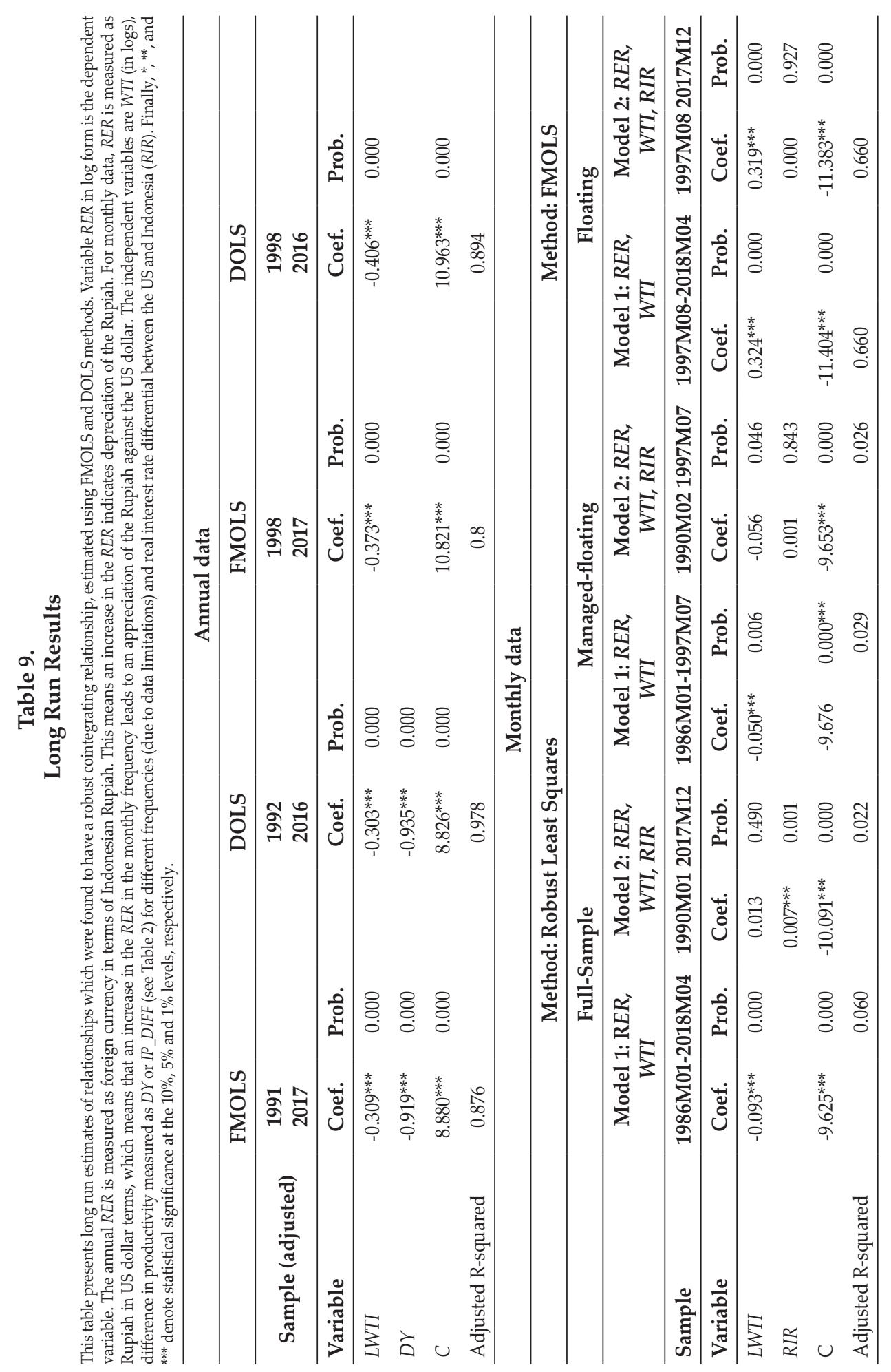




\section{CONCLUDING REMARKS}

This paper comprehensively examines the long-run relationship between the rupiah-US exchange rate and oil prices (WTI). Indonesia is a special case, since it an exporter as well as an importer of crude oil and petroleum products and switched from being a net exporter to a net importer of crude oil in 2013 and of partly refined petroleum products in 1997. During the study period (1986-2017), the nation also saw changes in the exchange rate regime, from a managed float to a float regime, and an active oil price subsidy policy. Three different cointegration tests, three different frequencies of data, and additional theoretical determinants of the exchange rate are used to establish the robustness of our key findings, which can be summarized as follows.

1. The rupiah, in nominal and real terms, was weaker against the US dollar but more volatile in the float period compared to the managed float period. During the float period, dependence on imported partly refined petroleum increased, with Indonesia becoming a net importer of partly refined petroleum in 1997.

2. In the presence of the Bitcoin, since August 2011, the real rupiah against the US dollar was, on average, stronger and less volatile than in the period prior to Bitcoin's introduction.

3. The finding in item (4) above holds after including in the models other determinants of the RER, namely, RIR and DY.

4. The advent of the Bitcoin may have affected the cointegrating relationship between WTI and RER. While we find robust evidence for a long run relation between WTI and RER in the floating period (point 3), for the more recent period of the floating period (August 2011 onwards) which marks the usage of Bitcoin in Indonesia, we could not find conclusive evidence of a cointegrating link between WTI and RER.

\section{REFERENCES}

Amano, R. A., and van Norden, S. (1998). Oil Prices and the Rise and Fall of the US Real Exchange Rate. Journal of International Money and Finance, 17, 299-316.

Basher, S. A., Haug, A. A., and Sadorsky, P. (2012). Oil Prices, Exchange Rates and Emerging Stock Markets. Energy Economics, 34, 227-240.

Camarero, M., and Tamarit, C. (2002). Oil Prices And Spanish Competitiveness: A Cointegrated Panel Analysis, Journal of Policy Modeling, 24, 591-605.

Chen, S. S., and Chen, H. C. (2007). Oil Prices and Real Exchange Rates. Energy Economics, 29, 390-404.

Corden, W.M. (1984). Booming Sector and Dutch Disease Economics: Survey and Consolidation, Oxford Economic Papers, 35, November, 359-80.

De Grauwe, P. (1996). International Money: Post War - Trends and Theories. Oxford: Oxford University Press.

Engle, R. F., and Granger, C. W. J. (1987). Cointegration and Error Correction: Representation, Estimations and Testing, Econometrica, 55, 251-276.

Ghosh, A., Guide, A.M., Ostry, J., and Wolf, H., (1997). Does the Nominal Exchange Rate Matter? National Bureau of Economic Research (Cambridge, MA) Working Paper No. 5874. 
Gulab, S. 1983. International Money: Post War - Trends and Theories. Oxford, Oxford University Press.

Husain, AM, Moody, A., and Rogoff, K. S. (2005). Exchange Rate Regime Durability and Performance in Developing versus Advanced Economy. Journal of Monetary Economics.

Johansen, S. (1988). Statistical Analysis of Cointegration Vectors. Journal of Economic Dynamics and Control, 12, 231-254.

Johansen, S. (1991). Estimation and Hypothesis Testing of Cointegration Vectors in Gaussian Vectors in Gaussian Vector Autoregressive models. Econometrica, 59, 1551-1580.

Johansen, S. (1995). Likelihood-Based Inference in Cointegrated Vector Autoregressive Models. New York: Oxford University Press.

Krugman, P. (1983). Oil shocks and exchange rate dynamics, In J. A. Frenkel (Ed.) Exchange rates and International Macroeconomics, 259-284. Chicago: University of Chicago Press.

Lizardo, R. A., and Mollick, A.V. (2010). Oil Price Fluctuations and US Dollar Exchange Rate. Energy Economics, 32, 399-408.

Ministry of Energy and Mineral Resources (MEMR). (2013). Ministry of Energy and Mineral Resources (MEMR) Regulation Number 07/2013.

Mundell, R. (1995). Exchange Rate Systems and Economic Growth. Rivista di Politica Economica, 85, 1-36.

Narayan, S. (2013). Foreign Exchange Rate Market and Oil Prices in Asia. Journal of Asian Economics, 28, 41-50.

Narayan, S., Sahminan, S. (2019). Has FinTech influenced Indonesia's exchange rate and inflation? Bulletin of Monetary Economics and Banking. Forthcoming.

Narayan, P., Narayan, S., Rahman, R. E., and Setiawan, I. (2019). Bitcoin Price Growth and Indonesia's Monetary System. Emerging Markets Review. Forthcoming.

Narayan, P., Popp, S. (2010). A new unit root test with two structural breaks in level and slope at unknown time. Journal of Applied Statistics, 37, 1425-1438.

Pesaran M.H., Shin Y. (1995). Autoregressive distributed lag modelling approach to cointegration analysis. DAE Working Paper Series No 9514, Department of Economics, University of Cambridge.

Pershin, V., Molero, J. C., and de Garcia, F. P. (2016). Exploring the Oil Prices and Exchange Rates Nexus in Some African Economies. Journal of Policy Modeling, 38, 166-180.

Queye, A.B., Mignon, V., and Penot, A. (2007). China and the Relationship between Oil Price and the Dollar. Energy Policy, 35, 5795-5806.

Rolnick, A.J., and Weber, W.E ., (1997). Money, Inflation, and Output under Fiat and Commodity Standards. Journal of Political Economy, 105, 1308-21.

Simorangkir, I., and Suseno. (2014). Exchange Rate System and Policies, Seri Kebanksentralan No.12. Bank Indonesia : Pusat Pendidikan dan Studi Kebanksentralan (PPSK).

Yeyati, E. L., and Sturzenegger, F., (2003). To Float or to Fix : Evidence on the Impact of Exchange Rate Regimes on Growth. The American Economic Review, 93, 1173-1193. 